\title{
Constructed wetlands aided with bio-preparation to neutralize wastewater from a small fruit and vegetable processing plant with high load pollutants
}

\author{
Monika Puchlik ${ }^{1, *}$ \\ ${ }^{1}$ Bialystok Technical University, Faculty of Civil and Environmental Engineering, Chemical \\ Laboratory, Wiejska Street 45E, 15-351 Bialystok, Poland
}

\begin{abstract}
The research was carried out for real wastewater collected directly from a fruit and vegetable plant located in north-eastern Poland. Effectiveness of organic matter metabolism expressed as $\mathrm{BOD}_{5}, \mathrm{COD}$, total suspended solids depending on the load of pollutants and biopreparation, was determined. The use of bio-preparation in the constructed wetland allowed to increase the efficiency of wastewater treatment throughout the research period: for $\mathrm{BOD}_{5}$ by $94 \%$ in deposit with biopreparation and by $87 \%$ in deposit without the addition of bio-preparation; however, for COD - by $93 \%$ in deposit with the addition of bio-preparation and by $87 \%$ in deposit without bio-preparation added.
\end{abstract}

\section{Introduction}

In rural areas, as well as with dispersed buildings, the problem is the treatment of sewage discharged from individual houses, their small clusters and small industrial plants that are not and will not be connected to collective sewage systems. Although the amount of wastewater discharged is small, they require treatment to the same extent as larger settling units $[1,2,17]$. Solution to the problem of wastewater treatment in small fruit and vegetable processing plants in non-urbanized areas may be the application of a proven, low-cost method of wastewater treatment using constructed wetlands. Properly designed and manufactured, they guarantee the required degree of treatment with sewage disposal to the ground or water. The constructed wetland method has found the widest application for the treatment of domestic wastewater. It can be used in agricultural areas where, due to the dispersion of buildings, it is more economical to build individual treatment plants than collective ones. It works perfectly in mountainous areas, valuable in nature, as well as in seasonally used facilities $[2,3]$. In the case of household wastewater treatment, it is most often used after preliminary mechanical treatment of sewage. The constructed wetland method can be applied in the second or third degree in sewage treatment plants operating

\footnotetext{
${ }^{*}$ Corresponding author: m.puchlik@pb.edu.pl
} 
using the activated sludge method or biological deposits. In the United Kingdom, a number of municipal wastewater treatment plants use rotary beds, and then constructed wetland with horizontal or vertical flow for wastewater treatment [4]. Such solutions can be applied in operating municipal and industrial wastewater treatment plants in order to increase the efficiency of their operation [5,6]. Their efficiency is high while ensuring proper operation and control of the treatment process, even for the smallest objects. Due to the possibility of removing various impurities, the constructed wetland systems are increasingly used for the treatment of industrial wastewater $[4,5]$. The reason for undertaking the research was the problems with the discharge and treatment of sewage from the small food industry plant in north-eastern Poland located in a scattered development area. The innovative nature of own research results from the lack of domestic and foreign experience in the field of treatment of wastewater originating from small plants of the fruit and vegetable industry using the constructed wetland method with subsurface vertical flow, grown with common reed, and additionally fed with bio-preparation to increase its operational efficiency. Obtained dependences concerning the influence of the analyzed factors on the amount of the removed load of selected pollutants in the constructed wetland deposit were confronted with general knowledge of this method of wastewater treatment. In the available literature, the assessment of significance of factors affecting the efficiency of contaminants removal in constructed wetlands is limited to the analysis carried out on the basis of percentage reduction of pollution. In this study, it was recognized that development of every dependence is possible only while taking into account the influence of factors such as pollution load, hydraulic load and mutual interactions between them [8].

\section{Application of constructed wetland and bio-preparation}

Constructed wetlands systems are most often used for the treatment of household sewage from individual settlements, but also rainwater, surface runoff, flowing waters, leachate from municipal waste landfills, and for drainage of sewage sludge [2, 3, 42]. They are also used for wastewater treatment from agro-food processing, which contains contaminations susceptible to biochemical degradation processes [7]. This solution was applied in the USA to wastewater from the vegetable industry and from sugar factories, as well as in New Zealand and Great Britain to wastewater from meat plants $[8,9]$. Interest in this convenient and pro-ecological solution is high enough that it is aimed at that they can work on any plot, regardless of ground conditions and the property size $[10,11]$. Undoubtedly, by opting for a household treatment plant, ecological benefits are gained. This definitely improves the cleanliness of waters in a given area. It is also worth paying attention to the aesthetic value of the constructed wetland treatment plant modeled on natural ecosystems providing shelter for birds, amphibians and insects associated with the aquatic environment. Thus, they allow to reduce the differences between natural and anthropogenic elements and a well-integrated constructed wetland treatment plant, which may increase the aesthetic values of a landscape. Vegetation growing in such treatment plant has a beneficial effect on the microclimate, reduces the wind speed and effects of heavy rainfalls $[1,12]$. There are known applications of constructed wetland systems for treatment of wastewater from farms, especially in the United States and Japan [13-15]. Constructed wetland systems can be used for treatment of wastewater from the cellulose industry [26]. In the United States and China, there are constructed wetland systems in refineries and mines. Other common applications of constructed wetland systems include cleaning the rain runoffs from roads and streets, bridges, petrol stations or airports [5]. Among sewage treated in vertical (VF) and horizontal (HF) flow systems, there are also wastewater from agro-food processing, which contain contaminants susceptible to biochemical degradation processes [7, 11]. This solution was used in the United States for wastewater from sugar factories, as well as in 
New Zealand and the United Kingdom for wastewater from meat plants [8, 9]. Interest in this convenient and pro-ecological solution is so big that it is aimed at that they can work on any plot, regardless of ground conditions and the property size $[10,11]$.

Bio-preparations are preparations, the main component of which are microorganisms or enzymes that influence the acceleration or support of the decomposition processes of organic compounds contained in wastewater, liquefaction of solid waste, preventing the formation of deposits, formation of so-called skin on the surface of the sewage. Biological wastewater treatment process consists in the decomposition of organic pollutants by microorganisms specially selected for this purpose. Bio-preparations are used both in municipal wastewater treatment plants as well as in individual farms, e.g. in cesspools or household wastewater treatment plants. A bio-preparation is composed of a starter conditioner and suitably selected composition of non-pathogenic microorganisms with strictly targeted effect, causing decomposition and degradation of harmful substances, like ammonia, nitrite, hydrogen sulfide, indole, skatole, mercaptans, phosphorus compounds and other mono- and multi-carbon organic compounds. The microbiological composite has the ability to bind heavy metals, direct the desired fermentation processes, change the $\mathrm{pH}$ of sewage and liquid manure, and strongly inhibit the development of pathogenic microorganisms, as well as enzymatic destruction of eggs and spores of insects and endoparasites [18]. Bio-preparations are manufactured in the form of tablets, powder, granules, emulsions and liquid. They usually contain selected strains of saprophytic bacteria, fungi and enzymes of natural origin. All microorganisms must belong to the first category of harmfulness, including microorganisms with low probability of causing diseases in humans and not posing any threat to the environment. In addition, biopreparations include, among others, carriers and nutrients for microorganisms and fragrances.

\section{Material and methods}

The paper presents the research upon the treatment of wastewater from the fruit and vegetable industry in constructed wetlands supported by a bio-preparation, which were carried out in 2014-2016. The deposit was fed with sewage from a small processing plant, that was created in the period from V to X (2014 and 2016) during washing, sorting and production of fruit and vegetable juices. The hydraulic load was $0.02 \mathrm{~m}^{3} / \mathrm{m}^{2} \mathrm{~d}$. One of the deposits was additionally supported by the bio-preparation (every 7 days in the amount of 4 grams per $1 \mathrm{~m}^{3}$ of raw sewage) that ensures the maintenance and reactivation of biological wastewater treatment plants. It is intended for wastewater with high COD parameters containing cellulose. It enriches biological deposits with microorganisms to improve their degradation properties. Samples of raw and treated wastewater were collected every 14 days from May 2014 to October 2016. The sewage treatment plant consists of a retention reservoir and two parallel systems consisting of ground and plant deposits with common reed (Phragmites australis). Ground and plant deposits have the dimensions of a square $-75 \times 75$ centimeters and depth of 80 centimeters. They were built in a system with the subsurface vertical flow of sewage. Deposits have four layers of filling, from the top: layer I (sand 0-2 mm, $0.15 \mathrm{~m}$ ), layer II (gravel 2-8 mm, $0.15 \mathrm{~m}$ ), layer III (fine gravel 8-20 mm, $0.20 \mathrm{~m}$ ), layer IV (stones $20-80 \mathrm{~mm}, 0.15 \mathrm{~m}$ ), on which the common reed (Phragmites australis) was planted. In the raw and treated sewage samples taken, in accordance with mandatory methodology, the following parameters were determined: COD - dichromate method according to: PN-74/C-04578.03 [37], $\mathrm{BOD}_{5}$ - manometric method using Oxi-Top Standard system, total suspended solids (TSS) - gravimetric method PN-EN 872:2007+Ap1:2007 [38]. 


\section{Results and discussion}

When analyzing the results of own research, a significant dispersion of the values for basic pollutants was noted (characteristic for sewage from the food industry) (Table 1). The highest variability was demonstrated by organic substance parameters expressed as $\mathrm{BOD}_{5}$ and COD as well as total suspended solids. According to the guide of the United States Environmental Protection Agency (US EPA 1994) [27], such a wide diversity of raw sewage quality creates the necessity of conducting local research to design the purification process. Figures $1-6$ show the relationships between the quantities of removed $\left(\mathrm{L}_{\mathrm{Rem}}\right)$ and delivered $\left(\mathrm{L}_{\text {Del. }}\right.$ ) loads vs. hydraulic load $\mathrm{q}_{\mathrm{h}}=0.02 \mathrm{~m}^{3} / \mathrm{m}^{2} \mathrm{~d}$. The amount of the removed load $\left(\mathrm{L}_{\mathrm{Rem}}\right)$ for $\mathrm{BOD}_{5}$ in the deposit with the addition of bio-preparation changed from 8.20 to $86.20 \mathrm{~g} \mathrm{O}_{2} / \mathrm{m}^{2} \mathrm{~d}$, while in deposit without bio-preparation - from 7.80 to $74.80 \mathrm{~g} \mathrm{O}_{2} / \mathrm{m}^{2} \mathrm{~d}$. Volume of the removed load $\left(\mathrm{L}_{\mathrm{Rem}}\right.$.) for $\mathrm{COD}$ in deposit with the addition of bio-preparation changed from 32.40 to $155.36 \mathrm{~g} \mathrm{O}_{2} / \mathrm{m}^{2} \mathrm{~d}$ and in deposit without biopreparation, it changed from 29.42 to $154.74 \mathrm{~g} \mathrm{O}_{2} / \mathrm{m}^{2} \mathrm{~d}$. For total suspensions, the amount of charge removed $\left(\mathrm{L}_{\mathrm{Rem}}\right.$. $)$ in deposit with the addition of bio-preparation changed from 22.18 to $56.80 \mathrm{~g} / \mathrm{m}^{2} \mathrm{~d}$. However, in deposit without bio-preparation, it changed from 21.74 to $55.80 \mathrm{~g} / \mathrm{m}^{2} \mathrm{~d}$. It was found that more organic substance expressed as $\mathrm{BOD}_{5}$ and COD as well as total suspended solids is removed in a bio-preparation-supported deposit, and thus a smaller pollutant load is discharged in treated wastewater $\left(\mathrm{L}_{\mathrm{Dis}}\right)$.

Table 1. Values of parameters in raw wastewater from the fruit and vegetable industry delivered to and discharged from the bio-preparation supported constructed wetland deposit and deposit without the addition of bio-preparation for the entire research period.

\begin{tabular}{|c|c|c|c|c|}
\hline Parameters & Unit & Raw wastewater* & $\begin{array}{l}\text { Wastewater treated with } \\
\text { bio-preparation } \\
\text { addition* }\end{array}$ & $\begin{array}{l}\text { Wastewater treated } \\
\text { without bio- } \\
\text { preparation addition* }\end{array}$ \\
\hline $\mathrm{BOD}_{5}$ & $\mathrm{mgO}_{2} \cdot \mathrm{dm}^{-3}$ & $\frac{2650}{500-4400}$ & $\frac{112.5}{10-440}$ & $\frac{332.5}{95-850}$ \\
\hline COD & $\mathrm{mgO}_{2} \cdot \mathrm{dm}^{-3}$ & $\frac{4162.7}{1760-7909}$ & $\frac{255.1}{127-539}$ & $\frac{483.3}{172-1037}$ \\
\hline TSS & $\mathrm{mg} \cdot \mathrm{dm}^{-3}$ & $\frac{1403.6}{1340-1490}$ & $32 \frac{704}{0-950}$ & $30 \frac{887}{8-840}$ \\
\hline
\end{tabular}

* numerator: the arithmetic mean; denominator: minimum-maximum, source-own research.

The effectiveness of organic substance removal expressed as $\mathrm{BOD}_{5}$ in the process of treatment of wastewater from the fruit and vegetable industry in the constructed wetland deposit during the whole research period with hydraulic load $q_{h}=0.02 \mathrm{~m}^{3} / \mathrm{m}^{2} \mathrm{~d}$ was $94.84 \%$ with added bio-preparation and $87.87 \%$ in the deposit without bio-preparation. Effectiveness of organic substance removal expressed as COD in the process of treatment of wastewater from the fruit and vegetable industry in the constructed wetland with medium deposit load $\mathrm{L}_{\text {Del. }}=83.26 \mathrm{~g} \mathrm{O}_{2} / \mathrm{m}^{2} \mathrm{~d}$ and hydraulic load $q_{h}=0.02 \mathrm{~m}^{3} / \mathrm{m}^{2} \mathrm{~d}$, was $93.05 \%$ for the deposit with added bio-preparation and $87.34 \%$ in the deposit without the addition of bio-preparation. Based on them, dependencies have been developed, which show that the higher the load of organic matter, the higher load is removed, and thus the higher efficiency of its removal. The removed load decreases slightly when the hydraulic load increases. Due to the lack of previous studies on the treatment of wastewater from the fruit and vegetable industry in bio-preparation supported constructed wetlands, achieved results can be confronted with the results obtained for the treatment of household sewage, municipal wastewater and treatment of leachate in constructed wetlands. Obtained results of research by Dąbrowski [3] in studies upon the treatment of leachate in vertical deposits showed 
lower efficiency of $\mathrm{BOD}_{5}$ removal $(87.3 \%$ to $89.8 \%)$ than it was achieved in own research in vertical deposit with the addition of bio-preparation, while higher than in deposit without bio-preparation. Lower efficiencies than those obtained in own research in deposit with and without the addition of bio-preparation, were reached by Liénard and Payrastre [21] for COD with a value of $83 \%$ in research conducted in the VF-CW deposit during household wastewater treatment, under load of COD $\left(\mathrm{L}_{\text {Del. }}=280 \mathrm{~g} \mathrm{O}_{2} / \mathrm{m}^{2} \mathrm{~d}\right)$. Results of research carried out by Troesch et al. showed the same efficiency - 93\% decrease in COD values in relation to those obtained in the own research in the constructed wetland with the addition of bio-preparation [36]. Higher (98.5\%, on average) efficiency in reducing $\mathrm{BOD}_{5}$ and $\mathrm{COD}$ values was obtained in studies conducted at a 6 times higher $\mathrm{BOD}_{5}$ load $\left(\mathrm{L}_{\text {Del. }}=329.5 \mathrm{~g} \mathrm{O}_{2} / \mathrm{m}^{2} \mathrm{~d}\right)$ and a comparable COD load $\left(\mathrm{L}_{\text {Del. }}=79.6 \mathrm{~g} \mathrm{O}_{2} / \mathrm{m}^{2} \mathrm{~d}\right)$ in municipal wastewater treatment in constructed wetland deposit [20]. In both cases, preservation of high loads with a simultaneous low hydraulic load was possible due to very high concentrations of organic matter, even several times higher than the average level observed in own research. Comparable results were obtained by Kengne et al. and Vincent et al. in the constructed wetland with the addition of bio-preparation during the treatment of household wastewater $[23,28]$. Very high $(95 \%)$ efficiency of organic substance removal expressed as COD was obtained by Koottatep et al. [39] in tests carried out with varying loads of total suspended solids, considerably higher than the load of TSS than in the own research. Kengne et al. reported the same effectiveness [23], carrying out tests with a load of suspended solids $100 \leq \mathrm{L}_{\text {Del. }} \leq 300 \mathrm{~kg} / \mathrm{m}^{2}$ year. High ( $88 \%$, on average) effectiveness of organic substance removal expressed as COD was demonstrated by Vincent et al. [28] in the research carried out with the deposit load of total suspended solids $\mathrm{L}_{\text {Del. }}=30$ and $\mathrm{L}_{\text {Del. }}=50 \mathrm{~kg} / \mathrm{m}^{2}$ year during the treatment of sewage in constructed wetlands. In all cases, the average value of COD in raw sewage delivered into the deposit was significantly higher than that observed in own research (respectively: 16000,31100 and $42000 \mathrm{mg} \mathrm{O}_{2} \mathrm{dm}^{-3}$, own study: $4400 \mathrm{mg} \mathrm{O}_{2} \mathrm{dm}^{-3}$ ). It can therefore be assumed that the organic matter load on the deposit was also higher. Observed regularity in the increase of organic substance removal efficiency along with the increase in the load of the constructed wetland was also confirmed by the results of studies carried out by Tanner [24] and Gajewska and Obarska-Pempkowiak [6]. This dependence is explained by the linear increase in the constant reaction rate along with the increase in the organic matter load of the deposit. According to Makowska et al. [30], the constructed wetland is a kind of biological deposit, in which development of a biomass is the more intense, the more loaded with pollution is the bioreactor. According to Sekułowicz et al. [29], high gravel deposit load with organic matter does not reduce their efficiency over time due to colmatation, but it causes its growth. This is explained by development of a biological membrane and plants inhabiting the deposit. In the case of deposits filled with fine-grained soil, overloading with the organic substance worsens the hydraulic conditions, which creates a high probability of colmatation $[8,31]$. As a result, after some time, the efficiency of removing impurities deteriorates [28]. The high efficiency of organic substance removal is determined by good aeration of the VF-CW deposits, which is achieved by means of their cyclic flooding [40]. Lower than in own research (both in deposit with the addition of bio-preparation and without it), the average treatment efficiency of dairy leachate delivered to the deposit was achieved by Dąbrowski et al. [32]. It changed for $\mathrm{BOD}_{5}$ by $81.8 \%$ on deposit with subsurface vertical sewage flow and by $72.7 \%$ on deposit with subsurface horizontal sewage flow during vegetation, as well as by $64.4 \%$ (SS VF) and $45.2 \%$ (SS HF), out of vegetation period [32]. Giuseppe et al. obtained lower values than those achieved in own research (COD $81 \%$, BOD $_{5} 79 \%$ ) of average efficiency in the HF-VF1-VF2 hybrid system (CW) for municipal wastewater [33]. Masi et al. studies have shown higher efficiency of municipal sewage treatment in two-stage CW systems in Moldova for COD 96\%, while 
lower for $\mathrm{BOD}_{5} 66 \%$ [34] than in own research (in the deposit with and without biopreparation). Milani et al. in multi-stage systems (CW) for the treatment of wastewater produced by a small winery in southern Italy (Sicily) showed average removal of COD in $79 \%$ [35], which is the lower value obtained in the research upon small fruit and vegetable processing plant on vertical deposit (both in deposit with and without the addition of bio-preparation). Results of studies conducted in Poland on household wastewater confirm a few percent reduction in the effectiveness of organic substance removal in the out-of-growing period [6]. Dependence of increasing the effect of hydraulic load increase on the reduction of the load removed in the out-of-growing period observed in the case of COD can be explained by lower intensity of biochemical processes in the out-of-growing period, which along with higher raw sewage flow rate through the constructed wetland and consequently shorter contact time with the biological membrane, contributes to lowering the efficiency of the process. Many authors emphasize that in the case of wastewater treatment with the use of constructed wetland, it is necessary to preliminarily remove the total suspended solids [25]. Brix and Arias [25] reported the efficiency of removing the TSS in $91 \%$ to $97 \%$ in vertical flow deposits. In turn, Vincent et al. [28] determined the effectiveness of removing total suspended solids based on the research carried out in France in eighty facilities. On average, it was $85 \%$. However, Obarska-Pempkowiak [6] during the treatment of leachates from anaerobic stabilization of sediments obtained a reduction in the concentration of total suspended solids from 452.10 to $56.10 \mathrm{mg} \cdot \mathrm{dm}^{-3}$ and 368.10 to 59.70 $\mathrm{mg} \cdot \mathrm{dm}^{-3}$, using a sequence of two vertical flow deposits. Lower efficiency of removing the TSS in wastewater from the fruit and vegetable industry in relation to ObarskaPempkowiak [6], Brix and Arias [25], was determined during the period of basic research. The results of own research showed similar tendency in removing total suspended solids $(72.25 \%)$ in the constructed wetland with the addition of bio-preparation and $49.80 \%$ in the constructed wetland deposit without the bio-preparation with medium load $\mathrm{L}_{\text {Del. }}=28.08 \mathrm{~g} / \mathrm{m}^{2} \mathrm{~d}$ and hydraulic load $q_{h}=0.02 \mathrm{~m}^{3} / \mathrm{m}^{2} \mathrm{~d}$. Troesch et al. [36] reported higher value of the efficiency of the total suspension removal, while lower than Brix and Arias [25]. Efficiency in the deposit without the addition of bio-preparation was lower than that obtained by other authors $(74.50 \%)$. On their basis, a relationship was developed, which shows that the load of total suspended solids increases as the delivered load is increased and decreases as the hydraulic load increases. This dependence is confirmed by the results of own research. Higher efficiency of removing the total suspended solids $(99 \%)$ was achieved by Kinsley and Crolla [22] in vertical deposit tests. Paing and Voisin [20] reached equally high efficiency in the treatment of municipal wastewater in vertical constructed wetland deposits. The deposit was operated with a load of total suspended solids $\mathrm{L}_{\text {Del. }}=46 \mathrm{~kg} / \mathrm{m}^{2}$ year and a comparable hydraulic load as that used in own research. Higher efficiency of removing the TSS than that obtained in the tests $(90 \%)$ was obtained by Kengne et al. [23] conducting research in a vertical deposit. Higher (81\%) effectiveness of removing total suspended solids was reported by Koottatep et al. [39] in research carried out upon the household wastewater as compared to own research, but lower than in the off-campaign period for a deposit with bio-preparation. The dehydrated solid fraction accumulated on the surface reduced the hydraulic capacity of deposit, reducing its effectiveness in the area of removing total suspended solids. Lower value $(53.2 \%)$ than in own research, was recorded by Soroko [7] for the efficiency of removing the TSS during industrial wastewater treatment in horizontal flow (HF) deposits with load $\mathrm{L}_{\text {Del. }}=626.00 \mathrm{~g} / \mathrm{m}^{2} \mathrm{~d}$. Relationship between the amount of load delivered and removed was also noticed by Gajewska and Obarska-Pempkowiak [6]. As the hydraulic load increases, the concentration in the outflow increases, thus the removed load decreases. However, in studies conducted by Vincent et al. [28], with a lower load of the total suspended solids $\mathrm{L}_{\text {Del. }}=30$ and $\mathrm{L}_{\text {Del. }}=50 \mathrm{~kg} / \mathrm{m}^{2}$ year, no statistically significant effect of load with the total 
suspended solids on the efficiency of their removal was observed. Although the efficiency of removing the TSS increases as the load of the constructed wetland increases, the majority of authors suggest the use of a preliminary mechanical wastewater treatment, which is one of the factors protecting the deposit against colmatation $[8,20]$.

\section{Conclusions}

Analysis of the measurements made allows the following statements:

1. Constructed wetlands with vertical flow assisted with bio-preparation purify wastewater from a small fruit and vegetable processing plant with high efficiency. In the constructed wetland with the addition of bio-preparation, there was no reduction in the efficiency of organic substance removal along with the increase in hydraulic load, which should result from shorter sewage contact time with the biological membrane developed in the deposit, and responsible for biochemical purification processes.

2. Enrichment of the biological membrane with nutrients by dosing bio-preparation in the constructed wetland allowed to increase the efficiency of wastewater treatment for organic substances known as $\mathrm{BOD}_{5}$ by 6.97 , COD by $5.71 \%$, and total suspended solids by $22.45 \%$, in relation to the deposit without the addition of bio-preparation.

3. Based on the obtained results of the treatment efficiency of wastewater from the fruit and vegetable industry in the constructed wetland, the relations between quantities of removed and delivered loads and hydraulic load were formulated, as well as their mutual interactions, which show that for all analyzed pollution indicators $\left(\mathrm{BOD}_{5}, \mathrm{COD}, \mathrm{TSS}\right)$, amount of the removed load increases with the increase of the delivered load in the examined range.

Acknowledgements The research has been carried out in the framework of project No. MB/WBiIŚ/13/2015 in Bialystok Technical University and financed from the funds for science MNiSW in Poland.

\section{References}

1. E. Burszta-Adamiak, M. Kęszycka, B. Ryglewska, Landscape Architecture, 2 (2008)

2. A. Jucherski., A. Walczewski, IBMER GCB (2009)

3. W. Dąbrowski, Purification of leachate from dairy plants in hydrophyte systems (Monography, 2014)

4. P. F. Cooper, Fundacão Calouste Gulbenkian (Lisbona, Portugal, 2003)

5. M. Puchlik, E3S Web of Conf. 44 (2018)

6. H. Obarska-Pempkowiak, M. Gajewska, E. Wojciechowska, (PWN, 2010)

7. M. Soroko, Water - Environment - Rural Areas 11, 1 (2011)

8. M. Puchlik, The effect of bio-preparation on the efficiency of wastewater treatment from the fruit and vegetable industry in constructed wetlands ( $\mathrm{PhD}$ Thesis, Poland, 2018)

9. C. M. Weedon, $9^{\text {th }}$ International Conference of Wetlands System for Water Pollution Control, France (2004)

10. Z. Dymaczewski, PZIiTS (Poznań, Poland, 2011) 
11. J. Ryńska, Household sewage treatment plants (Guide, Log InMedia, 2006)

12. M. Wolska, http://ladnydom.pl/budowa/1,113332,13137657 (2014)

13. J. A. Schafsma, C. Baldwin, C. Streb, Ecol. Eng. 14 (2000)

14. K. Kato, T. Koba, H. Ietsugu, T. Saigusa, S. Yanagijya, K. Kitagawa, S. Kobayashi, W CCin Japan (2007)

15. M. G. Haley, M. Rodgers, J. Mulqueen, Biores. Techn. 98 (2007)

16. B. Adrados, C. A Arias, L. M. Pérez, F. Codony, E. Becares, H. Brix, J. Morató, Ecol. Eng. 124 (2018)

17. M. Puchlik, J. Ecol. Eng. 17, 1 (2016)

18. M. Puchlik, K. Ignatowicz, W. Dąbrowski, J. Ecol. Eng. 16, 1 (2015)

19. M. Soroko, WERA 11, 1 (2011)

20. J. Paing, J. Voisin, Wat. Sci. Tech. 51, 9 (2005)

21. A. Liénard, E. Payrastre, Water Pollution Control (1996)

22. Ch. Kinsley, A. Crolla, AOWMA Annual Conference (2013)

23. I. M. Kengne, P.-H. Dodane, A. Amougou, D. Koné, Des. 248 (2009)

24. C. Tanner, Wat. Sci. Tech. 44, 11-12 (2001)

25. H. Brix, C. A. Arias, Ecol. Eng. 25, 5 (2005)

26. A. Hammer, B. P. Pullin, D. K Mc Murry, J. W. Lee, CWWQI (1993)

27. U.S. Env. Prot. Agency, Guide to Septage Treatment and Disposal, EPA Office of Research and Development, Washington (1994)

28. J. Vincent, P. Molle, C. Wisniewski, A. Liénard, IWA Water Pollution Control, Venice (2010)

29. J. Sekułowicz, A. Karczmarczyk, J. Mosiej, WSOW 2,18 (2006)

30. M. Makowska, M. Spychała, R. Błażejewski, J. Borowski, IWA Kraków, Poland (2005)

31. A. Karczmarczyk, J. Mosiej, Agricult. Univ. Land Recl. 35 (2004)

32. W. Dąbrowski, B. Karolinczak, D. Boruszko, P. Malinowski, IWA Water Pollution Control, Gdańsk, Poland (2016)

33. L. Giuseppe, Cirelli, S. Barbagallo, G. O. Conti, M. Ferrante, A. Marzo, M. Milani, IWA Water Pollution Control, Gdańsk, Poland (2016)

34. F. Masi, R. Bresciani, N. Martinuzzi, G. Cigarini, A. Rizzo, IWA Water Pollution Control, Gdańsk, Poland (2016)

35. M. Milani, S. Barbagallo, G. L. Cirelli, S. Consoli, A. Marzo, IWA Water Pollution Control, Gdańsk, Poland (2016)

36. S. Troesch, A. Liénard, P. Molle, G. Merlin, D. Esser, Wat. Sci. Tech. 60, 3 (2009)

37. PN-74/C-04578.03

38. PN-EN 872:2007+Ap1:2007

39. T. Koottatep, Ch. Polprasert, N. T. K. Oanh, U. Heinss, A. Montangero, M.Strauss, Elsevier (2001)

40. S. C. Reed, E. J. Middlebrooks, R. W. Crites, $2^{\text {nd }}$ ed. McGraw-Hill, NY (1995)

41. P. S. Rajendra, D. F. Fu, D. N. Fu, H. Juan, Arab. J Sci. Eng. (2014)

42. Y. Ogata, T. Ishigaki, Y. Ebie, N. Sutthasil, Ch. Witthayaphirom, Ch. Chiemchaisri, M. Yamada, Springer Japan KK, part of Springer Nature (2018) 